\title{
Studies on Shoot and Fruit Characters of Brinjal Plants and their Quantitative Relationships with Brinjal Shoot and Fruit Borer
}

\author{
E. Sowmya* and S. Pradeep \\ Department of Entomology, University of Agricultural and Horticultural Sciences, \\ Navile, Shimoga - 577 225, India \\ *Corresponding author
}

\section{A B S T R A C T}

\begin{tabular}{|l|}
\hline Ke y w o r d s \\
Brinjal shoot and \\
fruit borer, Shoot \\
and fruit characters, \\
Quantitative \\
relationship, \\
Infestation
\end{tabular}

\section{Introduction}

Brinjal, Solanum melongena Linnaeus is highly cosmopolitan and popular vegetable grown as poor man's crop in India. It is the most-consumed and most-sprayed vegetable in India, where it is grown on more than 5, 00,000 hectares, making it one of the main sources of cash for many farmers (Daniel Miller, 2007). The average yields of brinjal in India are reported to be 17.35 tonnes per hectare (Anon, 2011). Various insects cause enormous losses to this vegetable throughout the season in Bangladesh as well as in Indian sub- continent (Alam, 1969 and Dhankar, 1988), among them brinjal shoot and fruit borer (BSFB), Leucinodes orbonalis Guenee, is the most serious and destructive one. Due to the attack of this pest considerable damage is occurred each year affecting the quality and yield of the crop. Only the larvae of this pest cause $12-16 \%$ damage to shoots and 20-60\% to fruits (Alam, 1970; Maureal et al., 1982). The pest is very active during the rainy and summer season and often causes more than 90\% damage (Ali et al., 1980; Kalloo, 1988). 
The yield loss has been estimated up to $86 \%$ (Ali et al., 1980) in Bangladesh and up to 95\% (Naresh et al., 1986) in India. Indiscriminate use of synthetic chemicals for the controlling insect pest resulted hazardous effects causing serious problems including pest resistance, secondary pest outbreak, pest resurgence and environmental pollution. Considering the above fact, the present study was undertaken to find out whether the shoot and fruit characters influencing the infestation rate of BSFB and also their quantitative relationships with infestation which will help to develop resistant/tolerant varieties against this pest.

\section{Materials and Methods}

For the experiment thirty four brinjal cultivars were used. The experiment was laid out in a Randomized Complete Block Design (RCBD) with two replications. Uniform and healthy seedlings of 45 days old were taken separately from the seedbed, transplanted in the experimental plots maintaining a spacing of $75 \mathrm{~cm} \times 60 \mathrm{~cm}$ between the row to row and plant to plant. Different intercultural operations (weeding, gap filling and irrigation) were accomplished for better growth and development but no insecticide was used. The data on plant height $(\mathrm{cm})$, stem diameter $(\mathrm{cm})$, number of branches and leaves per plant, third leaf length $(\mathrm{cm})$, phenol content in shoot, fruit length $(\mathrm{cm})$, fruit weight $(\mathrm{g})$, mesocarp thickness $(\mathrm{cm})$, number of seeds, phenol content $(\mathrm{mg} / \mathrm{g})$, tannin content $(\mathrm{mg} / \mathrm{g})$ in fruit and infestation were recorded at 90 and 120 days after transplantation in shoot and fruit, respectively. Total phenols and tannin content from brinjal shoots and fruits were determined by method given by Bray and Thorpe (1954) and Sadashivam and Manickam (1996) and experiment was carried out in Microbiology Department, UAHS, and the College of Agricultural and Horticultural
Sciences, Navile, Shimoga. One ml of plant extract (alcohol evaporated after extraction with $80 \%$ alcohol) was pipetted out into a test tube. $1 \mathrm{ml}$ of folin-ciocalteu reagent followed by $2 \mathrm{ml}$ of $\mathrm{Na}_{2} \mathrm{CO}_{3}$ solution was added. Shakings were given to the tubes with automatic shaker and heated in a boiling water bath for exactly $1 \mathrm{~min}$. After boiling, solutions were allowed to cool and diluted the blue solution to $100 \mathrm{ml}$ with distilled water and absorbance was measured at $650 \mathrm{~nm}$ in a spectrophotometer. A blank containing all the reagents (without plant extract) was used to adjust the absorbance to zero. A standard graph was prepared by plotting absorbance V/Stannic acid concentration $(0.2,0.4,0.6$, 0.8 and 1.0). With the help of a standard graph, per cent total phenols were calculated and tannin content estimated by pipetted out Tannic acid working standard solutions (0.05 $\mathrm{mg} / \mathrm{ml}$ ) from $0.2-1 \mathrm{ml}$ to 5 individual test tubes, make up the volume to $1 \mathrm{ml}$ with distilled water. To each tube add $5 \mathrm{ml}$ of Folin-denis reagent was added followed by 10 ml of $35 \% \mathrm{Na}_{2} \mathrm{CO}_{3}$ solution mix the contents well and leave for incubation at room temperature for $30 \mathrm{~min}$. After the incubation read the absorbance at $700 \mathrm{~nm}$ against the reagent blank along with test samples. The experimental data recorded on various parameters during the investigation were analyzed statistically by adopting Fischer's method of analysis of variance as outlined by Gomez and Gomez (1976) and mean difference were adjusted with DMRT (Duncan, 1955).

\section{Results and Discussion}

Evaluation of traditional brinjal cultivars for shoot and fruit characters of brinjal in relation to shoot and fruit borer infestation (Table 14). The stem girth of various traditional brinjal cultivars ranged from $2 \mathrm{~cm}$ to $4 \mathrm{~cm}$ being maximum in mulla badane $(4 \mathrm{~cm})$, minimum in hosajavari badane $(2 \mathrm{~cm})$ and 
stem girth(-0.016) was non significant negative correlation with shoot and fruit borer infestation. But Hossain et al. (2002) reported that the stem diameter positively correlated (0.5472) with BSFB infestation. The genotype Apple badane $(55.4 \mathrm{~cm})$ showed maximum plant height whereas, minimum plant height showed Thailand badane $(24.2 \mathrm{~cm})$ and plant height $(-0.130)$ was non significant negative correlation with shoot and fruit borer infestation. But Hossain et al. (2002) reported that the plant height positively correlated (0.5310) with BSFB, L. orbonalis infestation. The average maximum third leaf length was recorded in the cultivar Sakleshpura badane $(9.15 \mathrm{~cm})$, minimum in doddamullina badane (3.9) and third leaf length $(-0.290)$ was non significant negative correlation with shoot and fruit borer infestation. But Hossain et al. (2002) reported that third leaf length $(\mathrm{cm})$ of selected brinjal genotypes was positively correlated (0.3158) with BSFB infestation.

Number of shoots ranged from 2.1 to 7 being maximum in Ramadurga badane (7), minimum in biliudda badane (2.1) and number of shoots (0.014) was positive non significant correlation with shoot and fruit borer infestation. The present findings are in line with Hossain et al. (2002) number of branches per plant was positively correlated (0.4180) with BSFB infestation.

The average maximum numbers of leaves were recorded in the cultivar dorelo badane (72) and in the cultivar biliudda badane (12.1) and number of leaves (0.064) was non significant positive correlation with shoot and fruit borer infestation. But Hossain et al. (2002) observed that the number of leaf per plant were positively correlated (0.3968) with BSFB infestation. Cultivars had the maximum number of trichomes on the leaf surface of Sakleshpura badane (17.55), minimum in bilichendu badane (9.7) and leaf trichomes ($\left.0.391^{*}\right)$ was negatively significantly correlated with shoot and fruit borer infestation due to more number of trichomes reduces shoot and fruit borer infestation.

The present findings were in line with Javed et al., 2011, who reported that the trichomes and hairs on different parts of the plant seem to have a significant role towards non preference for fruit infestation which is in conformity with the findings of Hossain et al., (2004).

According to them, less number of trichomes may be responsible for the susceptibility of brinjal plant to shoot and fruit borer. The traditional cultivars was found to have varying levels of Phenol content in shoot, ranging from $162.5 \mathrm{mg} / 100 \mathrm{gm}$ to 784 $\mathrm{mg} / 100 \mathrm{gm}$ being maximum in Heddaragulla badane (761 $\mathrm{mg} / 100 \mathrm{gm})$, minimum in annageri badane $(162.5 \mathrm{mg} / 100 \mathrm{gm})$ and phenol content $(-0.710 * *)$ was significantly negatively correlated with shoot and fruit borer infestation due to cultivars with maximum amount of Phenol content received the minimum infestation in both shoot and fruit due to phenol content impart resistance against brinjal shoot and fruit borer.

Findings of the present study are supported by several earlier investigators Martin (2004) and Doshi (2004) also reported that PPO activity had a high negative direct effect on shoot and fruit borer infestation. The maximum fruit length $6.95 \mathrm{~cm}$ was recorded in Apple badane and minimum fruit length reported in kothithale badane $(2.4 \mathrm{~cm})$ and fruit length (0.301) was non significant negative correlation with shoot and fruit borer infestation. Similar findings were reported by Grewal and Singh (1995) and Gupta and Kauntey (2008) who did not find any linear correlation between length and diameter of fruits and degree of fruit infestation (Fig. 1 and 2). 
Table.1 Morphological and biochemical characters of brinjal plant in relation to shoot infestation

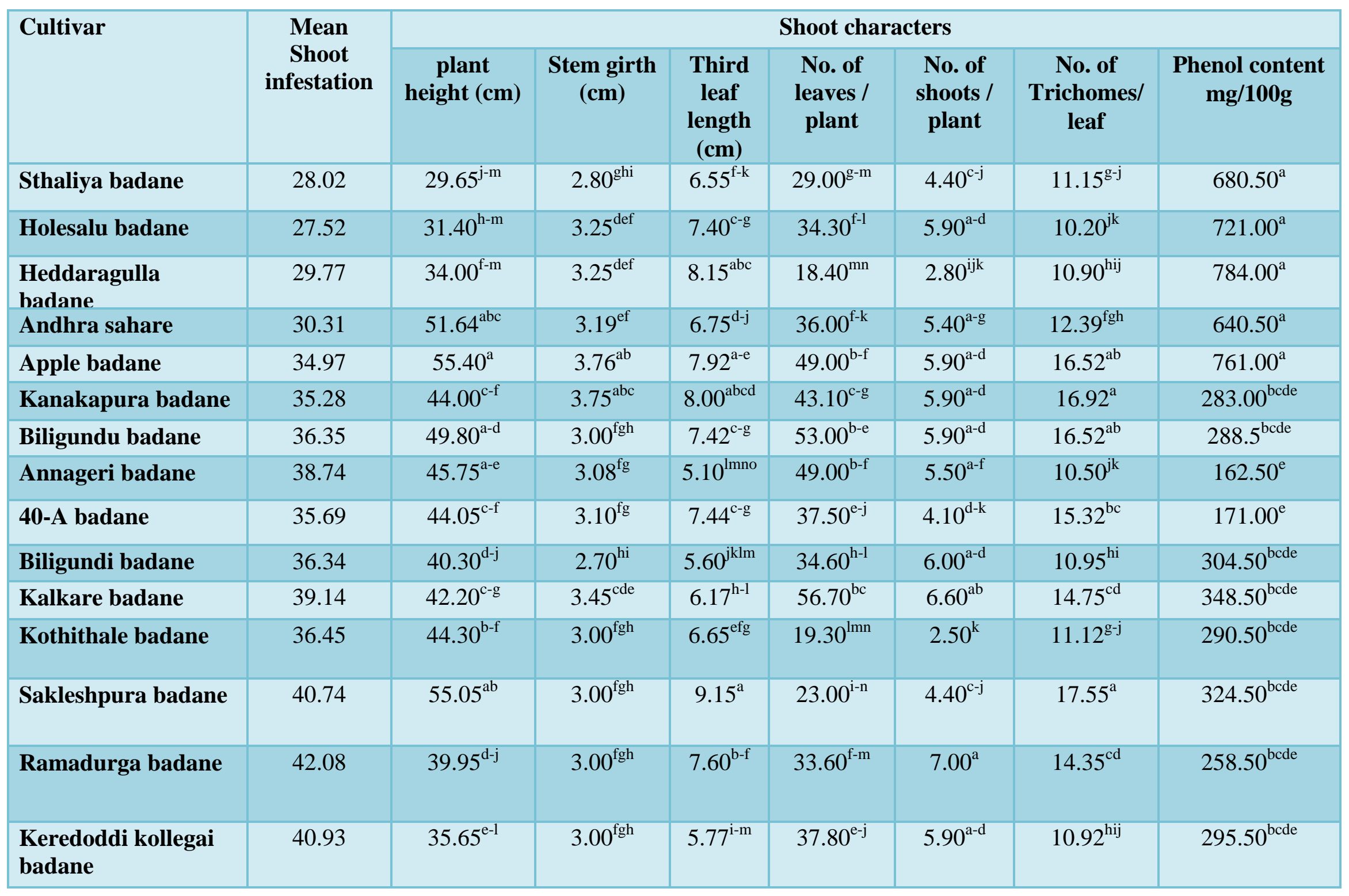




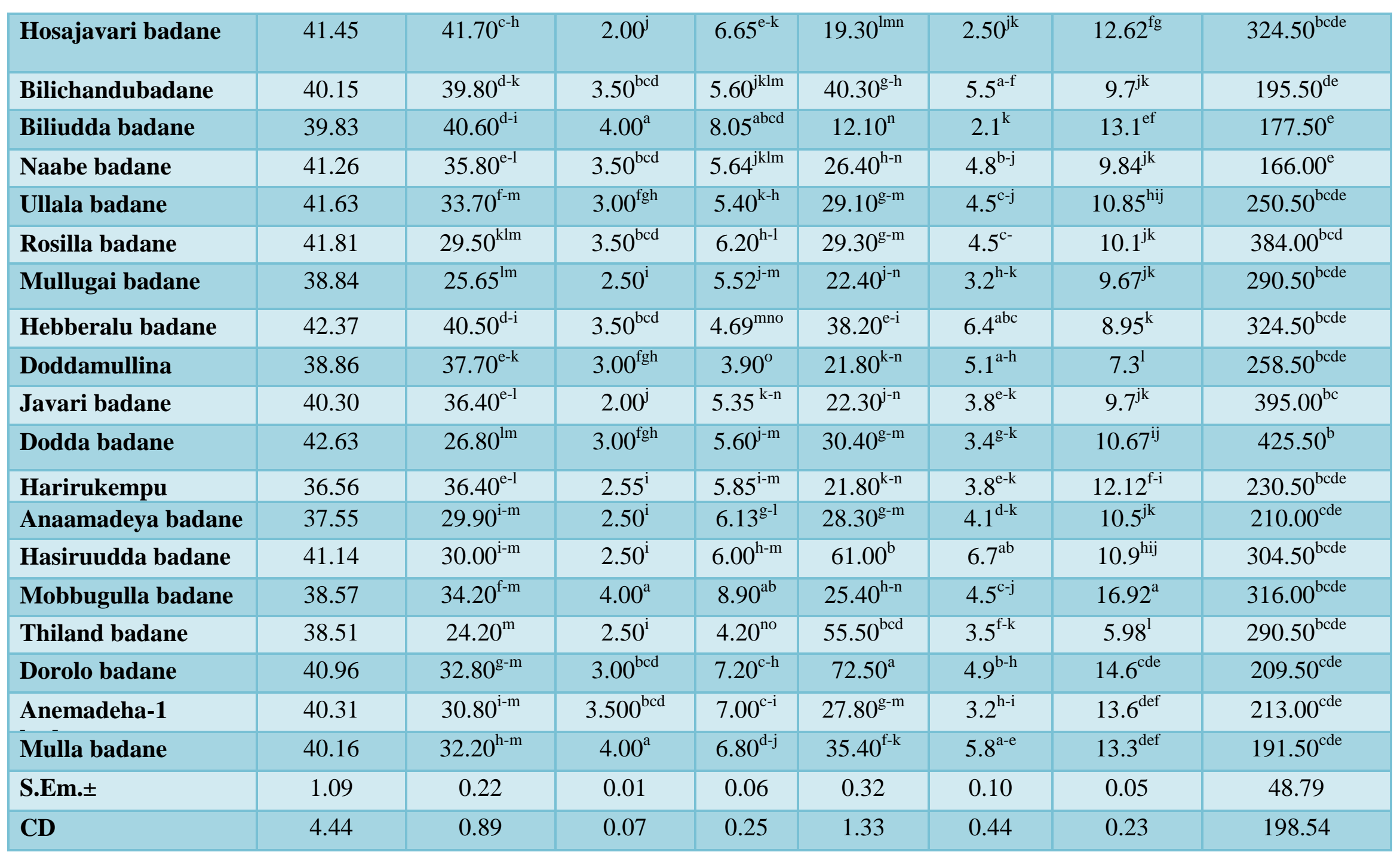

Values in each column superscripted by same letter do not differ significantly 
Table.2 Correlation between shoot infestation and plant characters

\begin{tabular}{|c|c|c|c|c|c|c|c|}
\hline Characters & Plant height (cm) & $\begin{array}{l}\text { Stem girth } \\
(\mathrm{cm})\end{array}$ & $\begin{array}{l}\text { Third leaf } \\
\text { length }(\mathrm{cm})\end{array}$ & $\begin{array}{l}\text { No. of } \\
\text { leaves/plant }\end{array}$ & $\begin{array}{l}\text { No. of } \\
\text { shoot/plant }\end{array}$ & $\begin{array}{l}\text { No. of } \\
\text { Trichomes/ leaf }\end{array}$ & $\begin{array}{l}\text { Phenols } \\
\text { (mg/100g) }\end{array}$ \\
\hline Shoot infestation & -0.130 & -0.016 & -0.290 & 0.064 & 0.014 & $-0.391 *$ & $-0.710 *$ \\
\hline
\end{tabular}

Table.3 Morphological and biochemical characters of brinjal fruit in relation to fruit infestation

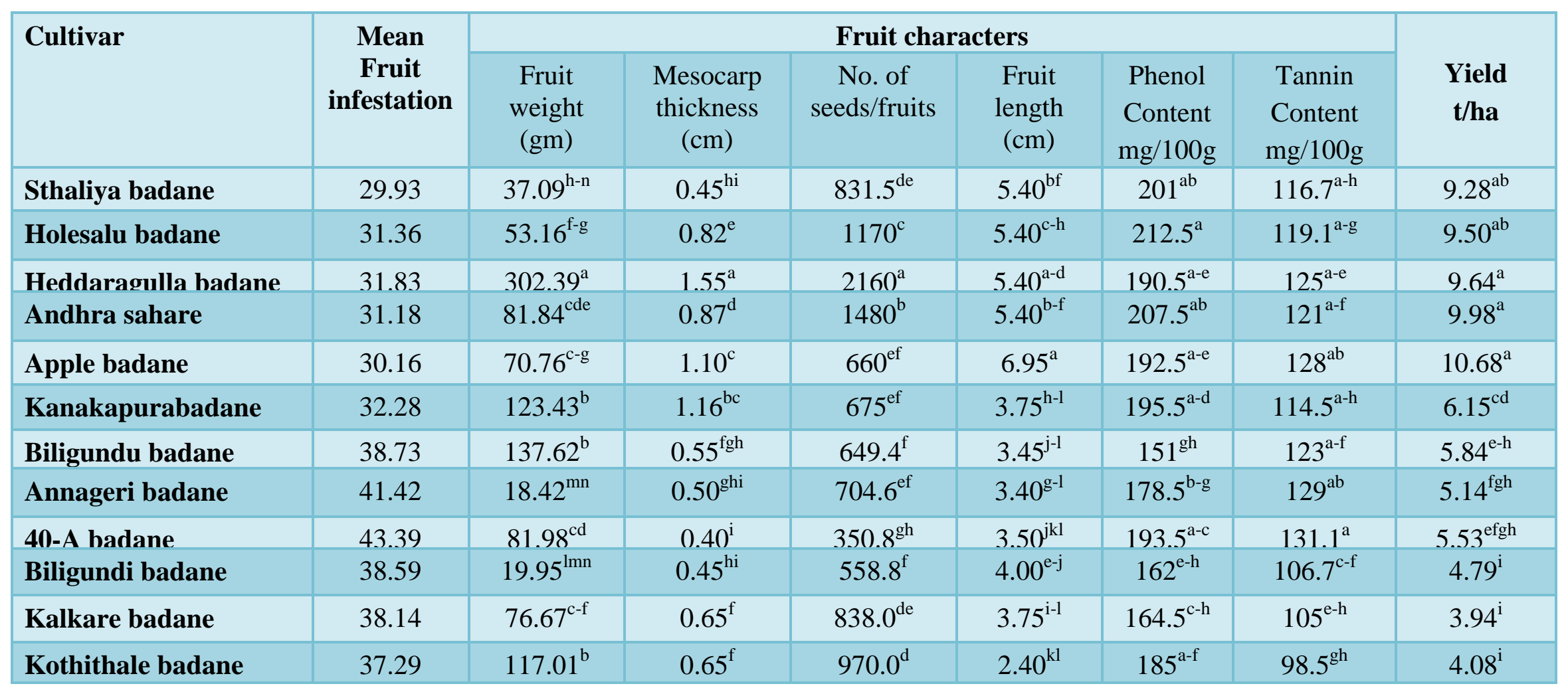




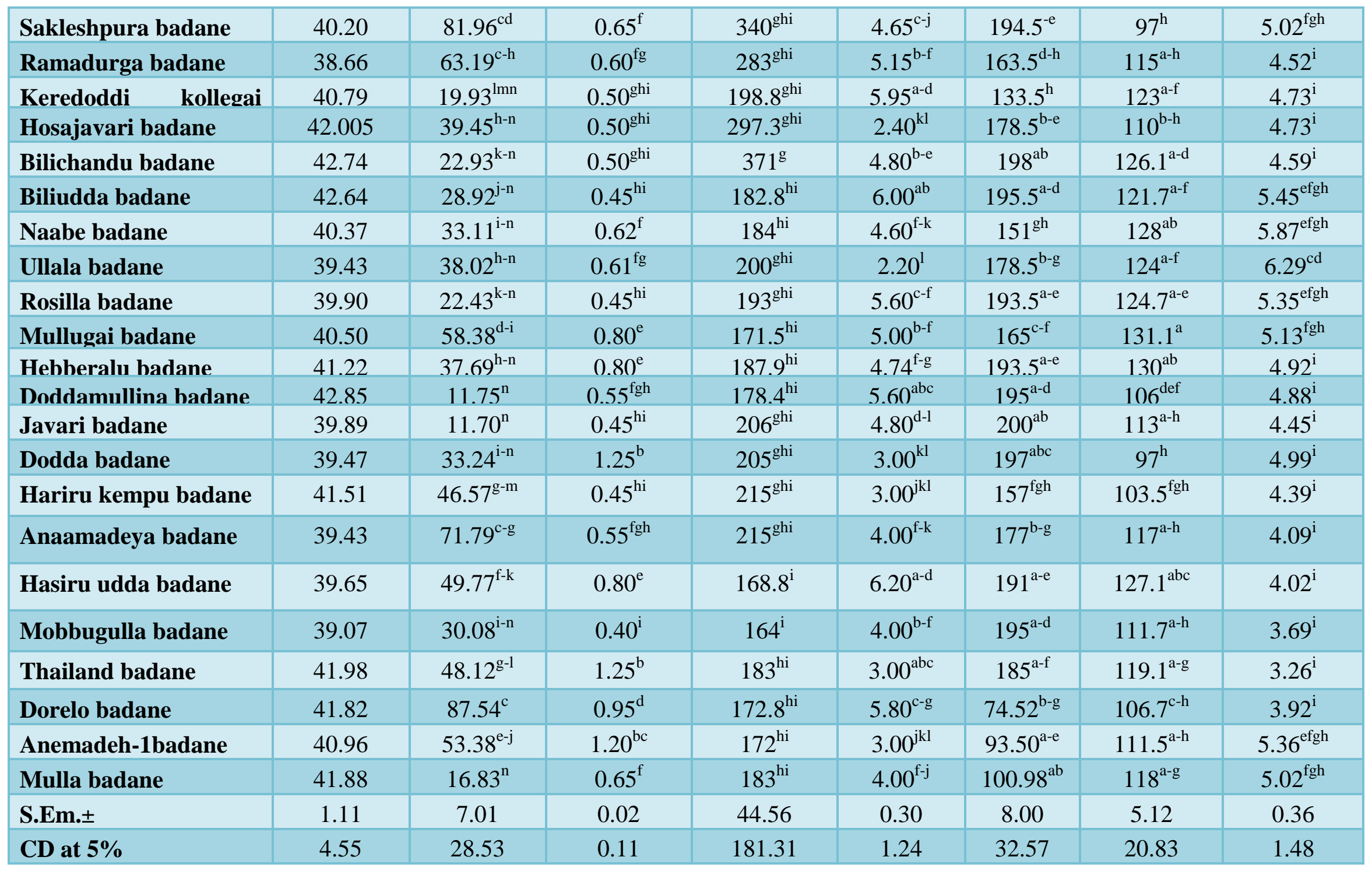


Table.4 Correlation between fruit infestation and fruit characters

\begin{tabular}{|l|c|c|c|c|c|c|c|}
\hline Characters & $\begin{array}{c}\text { Fruit } \\
\text { Weight } \\
\text { (g) }\end{array}$ & $\begin{array}{c}\text { Mesocarp } \\
\text { Thickness } \\
(\mathbf{c m})\end{array}$ & $\begin{array}{c}\text { No. } \\
\text { of seeds }\end{array}$ & $\begin{array}{c}\text { Fruit } \\
\text { Length } \\
(\mathbf{c m})\end{array}$ & $\begin{array}{c}\text { Phenol } \\
\text { content } \\
(\mathbf{m g} / \mathbf{g})\end{array}$ & $\begin{array}{c}\text { Tannin } \\
\text { content } \\
(\mathbf{m g} / \mathbf{g})\end{array}$ & Yield \\
\hline Fruit infestation & $-0.455^{* *}$ & $-0.389^{*}$ & $-0.740^{* *}$ & -0.301 & $-0.357^{*}$ & -0.052 & $-0.825^{* *}$ \\
\hline
\end{tabular}

**. Correlation is significant at 0.01 level (2-tailed).

*. Correlation is significant at 0.05 level (2-tailed)

$\mathrm{N}=34$

$\mathrm{r}=0.389$

Fig.1 Correlation between physico-morphic and biochemical characters of shoots of traditional brinjal cultivars against shoot and fruit borer

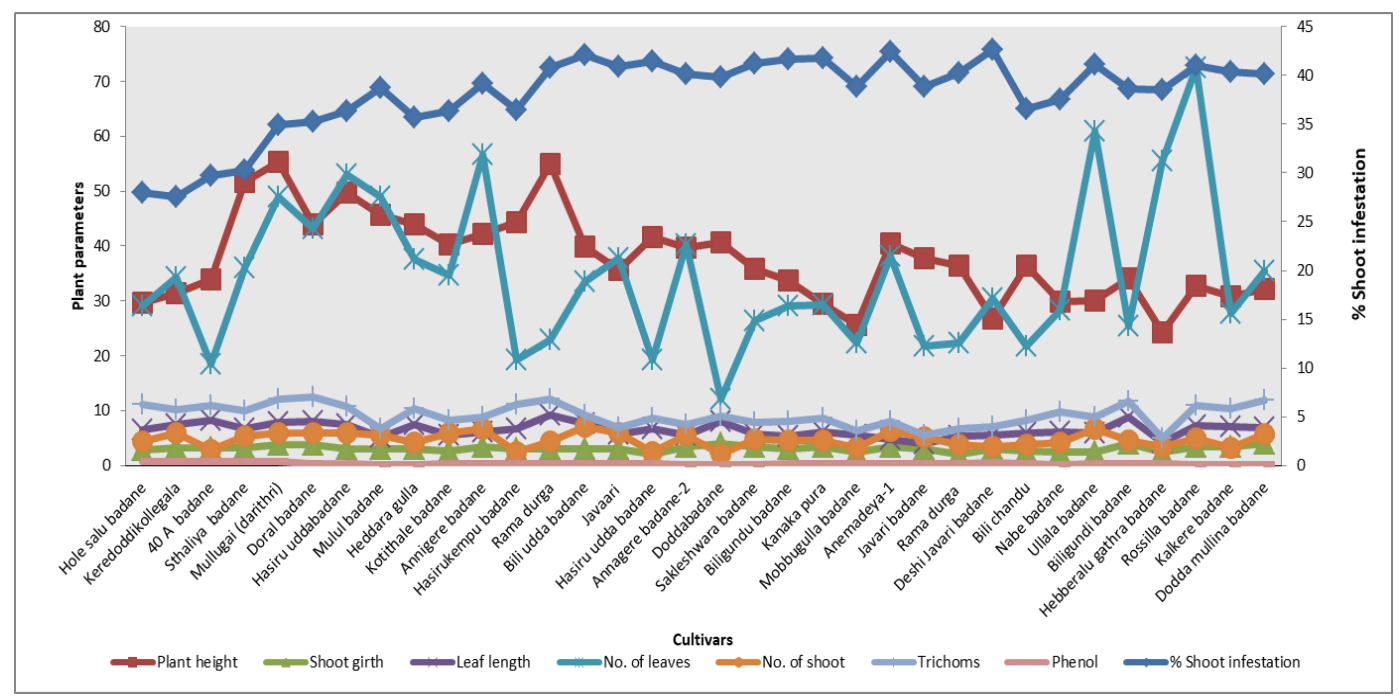

Fig.2 Correlation between physico-morphic and biochemical characters of fruits of traditional brinjal cultivars against shoot and fruit borer

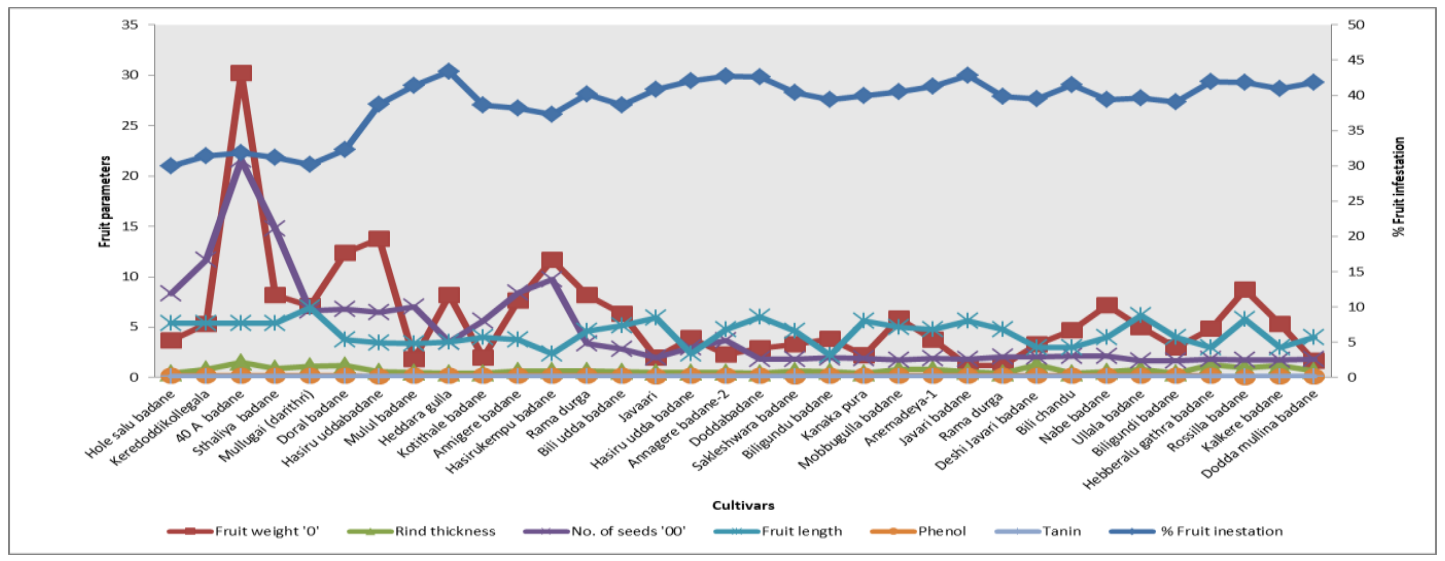


The maximum fruit weight 302.39 gm was recorded in heddaragulla badane (302.39 gm) whereas, minimum fruit weight reported in Javari badane (11.70 gm) and fruit weight ($\left.0.455^{* *}\right)$ was significant negative correlation with shoot and fruit borer infestation. Similar findings were reported by Hazra et al., 2004, there was a positive and significant effect of fruit weight $(0.45)$ on the susceptibility to fruit infestation of the pest. The maximum mesocarp thickness reported in the cultivar heddaragulla badane $(1.55 \mathrm{~cm})$ whereas, minimum in $40-\mathrm{A}$ badane $(0.4 \mathrm{~cm})$ and mesocarp thickness $\left(-0.389^{*}\right)$ was significant negative correlation with shoot and fruit borer infestation. These findings are in line with Krishnaiah and Vijay (1975). According to them susceptibility might be due to the spherical and oblong fruit with soft mesocarp and loosely arranged seeds. The maximum number of seeds 2160 was recorded in heddaragulla badane, the minimum number of seeds was noticed in mobbugulla badane (164) and number of seeds $(-0.740 * *)$ was non significant negative correlation with shoot and fruit borer infestation. The literature on this aspect of study is lacking in case of brinjal to compare and discusses the present results and therefore this study forms first of its kind. The maximum tannin content $131.1 \mathrm{mg} / 100 \mathrm{gm}$ was recorded in 40 -A badane and mullugai badane, minimum in kothithale badane $(97 \mathrm{mg} / 100 \mathrm{gm})$ and tannin content (0.052) was non significant negative correlation with shoot and fruit borer infestation. The maximum phenol content reported in holesalu badane $(212.5$ $\mathrm{mg} / 100 \mathrm{gm})$, minimumin dorelo badane (74.5 $\mathrm{mg} / 100 \mathrm{gm})$ and phenol content $\left(-0.357^{*}\right)$ was significant negative correlation with shoot and fruit borer infestation and findings of the present study are supported by Doshi (2004) also reported that PPO activity had a high negative direct effect on shoot and fruit borer infestation. Maximum yield was recorded in Apple badane (10.68 $\mathrm{t} \mathrm{ha}^{-1}$ ) and the minimum yield was recorded in Thailand badane (3.26 t $\left.\mathrm{ha}^{-1}\right)$. However, the yield was significant negative correlation with incidence of shoot borer $\left(-0.825^{* *}\right)$.

\section{References}

Alam, M.Z. 1970. Insect pest of vegetables and their control in Bangladesh. Agril. Inf. Serv. Dacca, Bangladesh. 132 p.

Ali, M.I., Ali, M.S. and Rahman, M.S. 1980. Field evaluation of wilt disease and shoot and fruit borer attack of different cultivars of brinjal. Bangladesh J. Agril. Sci. 7(2): 193-194.

Anonymous, 2011, Indian Horticulture Database, National horticulture board, 2011, Ministry of Agriculture, Government of India. at $w w w$. nhb.go.in.

Bray, H. G. and Thorpe, W. V., 1954, Analysis of phenolic compounds of interest in metabolism. Methods of Biochemical Analysis, 1: -27-52.

Daniel Miller. 2007. Genetically Engineered Eggplant. Span, 41.

Dhankar, B. S., 1988, Progress in resistance studying in Eggplant (Solanum melongena L.) against shoot and fruit borer (Leucinodes orbonalis Guenee) infestation. Trop. pest Manag., 34: 343345.

Doshi, K. M., 2004, Influence of biochemical factors on the incidence of shoot and fruit borer infestation in eggplant. Capsicum and Eggplant Newsletter, 23: 145-148.

Duncan, D.V. 1955. Multiple Ranges and Multiple F- test. Biometrics. 11:1- 42.

Gomez, K. A. and Gomez, A. A., 1976, Statistical procedure for agricultural research ( $2^{\text {nd }}$ Ed.). A Willey Inter. sci. Publs., New York. p.680.

Grewal, R. S., SINGH AND Dilbagh, 1995, Fruit characters of brinjal in relation to infestation by L. orbonalis Guen. Indian 
J. Ent,. 57: 336-343.

Gupta Y. C. and Kauntey, R. P. S., 2008, Studies on fruit characters in relation to infestation of shoot and fruit borer, Leucinodes orbonalis Guen. in brinjal Solanummelongena Linn. J. Ent. Res., 32: 119-123.

Hazra, P., R. Dutta and T. K. Maity. 2004. Morphological and biochemical characters associated with field tolerance of brinjal (Solanum Melongena L.) to shoot and fruit borer and their implication in breeding for tolerance. Indian J. Genet., 64(3): 255256.

Hossain, M. M., M. Shahjahan and A. K. M. Saad-UD-Doula Prodhan. 2002. Study of anatomical characters in relation to resistance against brinjal shoot and fruit borer. Pak. J. Biol. Sci., 5(6): 672-678.

Kalloo. 1988. Solanaceous crops. In: Vegetable Breeding. Vol. II. CRC. Press. INC BOCA Raton, Florida. pp. 520-570.

Krishnaiah, K. and Vijay, O. P. 1975.
Evaluation of brinjal varieties for resistance to shoot and fruit borer, Leucinodes orbonalis Guen. Indian Journal of Horticulture, 32 (1-2): 84-86.

Martin, S., 2004, Biochemical and molecular profiling of diversity in Solanum spp. and its impact on pests. An Msc thesis inBiotechnology, Tamil Nadu Agril. Univ., p.124.

Maureal, A. M., Noriel, L. M. and Esguerra, N. M. 1982. Life history and behaviour of eggplant fruit borer. Annal. Trop. Res. 4(3): 178.

Naresh, J. S., Malik, V. S., Balan, J. S. and Khokhar, K. S. 1986. A new record of Trathala sp., a larval endoparasite attacking brinjal fruit borer, Leucinodes orbonalis Guenee. Bull. Ent. New Delhi. 27(1): 74.

Sadashivam, S. and Manickam, A., 1996, Biochemical methods. New age international $(P)$ Ltd., publishers, (Edn. 2), May.

\section{How to cite this article:}

Sowmya, E. and Pradeep, S. 2020. Studies on Shoot and Fruit Characters of Brinjal Plants and their Quantitative Relationships with Brinjal Shoot and Fruit Borer. Int.J.Curr.Microbiol.App.Sci. 9(08): 3592-3601. doi: https://doi.org/10.20546/ijcmas.2020.908.414 